\title{
The
}

\section{Research Universities}

\section{and Their Patrons}




\section{ADVISORY COMMITTEE}

Thomas A. Bartlett president, Association of American Universities

Willard L. Boyd president, University of lowa William G. Bowen president, Princeton University

William H. Danforth chancellor, Washington University Sheldon HaCKNeY president, University of Pennsylvania ARTHUR G. Hansen president, Purdue University STEVen Muller president, Johns Hopkins University JAMES C. Olson president, University of Missouri DAvid S. SAXON president, University of California System Robert H. Strotz president, Northwestern University Charles E. Young chancellor, University of California, Los Angeles

James I. Armstrong president, Charles A. Dana Foundation RichaRD LyMAN president, Rockefeller Foundation ROBERT L. PAyton president, Exxon Education Foundation Alan Pifer president, Carnegie Corporation of New York Albert ReEs president, Alfred P. Sloan Foundation JoHN E. SAwyer president, Andrew W. Mellon Foundation FRANKLIN ThOMaS president, Ford Foundation EDWARD DONLEY chairman, Air Products and Chemicals Gerald D. Laubach president, Pfizer, Incorporated WILLIAM F. MilleR president, SRI International Morris TANenbaum executive vice-president, AT\&T 


\section{The \\ Research \\ Universities \\ and Their Patrons}

ROBERT M. ROSENZWEIG

with

Barbara Turlington

Prepared under the auspices of the Association of American Universities

University of California Press

Berkeley - Los Angeles a London 
University of California Press

Berkeley and Los Angeles, California

University of California Press, Ltd.

London, England

(C) 1982 by

The Regents of the University of California

Library of Congress Cataloging in Publication Data

Rosenzweig, Robert M.

The research universities and their patrons.

Includes index.

1. Research institutes-United States. 2. Federal aid to research-United States. 3. Science and stateUnited States. I. Turlington, Barbara. II. Title.

Q180.U5R67 001.4'0973 81-19685

ISBN 0-520-04664-1 AACR2

Printed in the United States of America

$\begin{array}{lllllllll}1 & 2 & 3 & 4 & 5 & 6 & 7 & 8 & 9\end{array}$ 